Article

\title{
Groundwater Table Effects on the Yield, Growth, and Water Use of Canola (Brassica napus L.) Plant
}

\author{
Hakan Kadioglu ${ }^{1}$, Harlene Hatterman-Valenti ${ }^{2}$, Xinhua Jia ${ }^{3}$, Xuefeng Chu ${ }^{4}$, Hakan Aslan ${ }^{5}$ \\ and Halis Simsek $2, *$ (D) \\ 1 School of Natural Resource Sciences, North Dakota State University, Fargo, ND 58105, USA \\ 2 Agricultural \& Biosystems Engineering, North Dakota State University, Fargo, ND 58105, USA \\ Plant Science, North Dakota State University, Fargo, ND 58105, USA \\ 4 Civil \& Environmental Engineering, North Dakota State University, Fargo, ND 58105, USA \\ 5 Farm Structure and Irrigation, Ondokuz Mayis University, 55270 Samsun, Turkey \\ * Correspondence: halis.simsek@ndsu.edu; Tel.: +1-701-231-6107
}

Received: 3 July 2019; Accepted: 17 August 2019; Published: 20 August 2019

\begin{abstract}
Lysimeter experiments were conducted under greenhouse conditions to investigate canola (Brassica napus L.) plant water use, growth, and yield parameters for three different water table depths of 30,60 , and $90 \mathrm{~cm}$. Additionally, control experiments were conducted, and only irrigation was applied to these lysimeters without water table limitations. The canola plant's tolerance level to shallow groundwater was determined. Results showed that groundwater contributions to canola plant for the treatments at 30,60 , and $90 \mathrm{~cm}$ water table depths were $97 \%, 71 \%$, and $68 \%$, respectively, while the average grain yields of canola were $4.5,5.3$, and $6.3 \mathrm{gr}$, respectively. These results demonstrate that a $90 \mathrm{~cm}$ water table depth is the optimum depth for canola plants to produce a high yield with the least amount of water utilization.
\end{abstract}

Keywords: lysimeter; canola; water table; water use efficiency; root distribution; evapotranspiration

\section{Introduction}

As the global population grows, the demand for fresh water in many regions has increased dramatically. These population increases have caused more water stress for agriculture, the production of energy, industrial uses, and human consumption. Even though many countries currently have not faced a lack of water, water can no longer be considered an infinite source. Numerous regions have water use restrictions, so additional strategies to decrease the impact of water crises across the globe are needed [1-3].

One strategy for agricultural water management would encourage farmers to use shallow groundwater. Approximately $80 \%$ of available water resources in the world are being used in agricultural applications, and, therefore, the gap between adequate water availability and water needs is increasing [2]. Hence, the management of groundwater utilization in agriculture may be an acceptable alternative strategy to reduce freshwater demand. Therefore, surface water and shallow groundwater resources have become important for water demands.

Water use efficiency (WUE) is defined as a grain crop yield or total crop biomass per unit of water use [4]. Improved and well-managed WUE in agricultural water management systems is an important strategy to increase the productivity and reliability of crop yields. The consumption of groundwater is an extremely significant part of WUE. However, describing WUE for irrigation is complicated [5].

Good quality groundwater is a supplemental irrigation water source that can supply crops' water demands. When managed correctly, shallow groundwater can reduce both drainage and irrigation requirements. Some crops, such as canola (Brassica napus L.), soybean (Glycine max), and safflower 
(Carthamus tinctorius), are able to use moderate saline groundwater and could help to increase the utilization of groundwater and decrease the utilization of surface irrigation water $[1,6,7]$. In addition, there are obvious relationships between water table management (WTM), crop productivity, and environmental pollution. The environmental and economic benefits of WTM could decrease environmental pollution and increase crop productivity and irrigation intervals. However, WTM must be utilized correctly to supply sufficient soil moisture content to the crops [8].

The consumption of shallow groundwater as a crop water supply depends on several factors, such as groundwater table depths, groundwater availability and quality, crop species, distribution of the plant root system, weather conditions, and soil types [7,9]. The quantity and quality of groundwater are also affected by the irrigation method and management practices, as an excessive amount of irrigation water will increase groundwater utilization. It is impossible to control all these factors under field conditions because groundwater contributions are highly variable and difficult to estimate. Therefore, lysimeters are often used to evaluate a single parameter at a time [10].

Mejia et al. [8] utilized lysimeters to determine the effect of two different water table depths (50 and $75 \mathrm{~cm}$ ) on corn and soybean grain yields. A free drainage system was installed $100 \mathrm{~cm}$ below the soil surface for both treatments. In the first year, corn yield was determined to be $13.8 \%$ higher with the free drainage treatment compared to the treatment without drainage at the $50 \mathrm{~cm}$ water table depth. However, only a $2.8 \%$ corn yield increase was observed at the $75 \mathrm{~cm}$ water table depth. In the second year, corn yield increases with the free drainage treatment compared to no drainage were measured as $6.6 \%$ at the $50 \mathrm{~cm}$ water table depth and $6.9 \%$ at the $75 \mathrm{~cm}$ water table depth. Similar results were observed for soybean. The authors concluded that the $75 \mathrm{~cm}$ water table depth with a free drainage system for corn and soybean was the most efficient water table depth.

Luo and Sophocleous [10] used lysimeters to evaluate the influence of the groundwater evaporation's contribution to winter wheat crop water use. Different water table depths, climates, and irrigation conditions were used to determine the amount of crop water use from the desired groundwater table levels. The relationship between wheat crop water use and water table depth varied. Winter wheat was supplied with $75 \%$ of crop water-use from a $100 \mathrm{~cm}$ groundwater depth without an irrigation application, while 3\% of crop water use was supplied from the $300 \mathrm{~cm}$ groundwater level with three irrigation applications. The results showed that the water table contribution was affected not only by the water table depth, but also by the soil profile, rainfall, irrigation, and climatic variations.

Plant water uptake from shallow groundwater is affected by water table depth, plant salt tolerance, and plant root characteristics, the soil's hydraulic properties, the salinity level of the groundwater, and the presence of irrigation and drainage systems. Plant salt tolerance is the leading factor affecting water extraction from shallow groundwater. Each plant has a different tolerance to salinity, and plant tolerance differs in each growth stage. All the plants tend to be more susceptible to salinity in their early stages [11,12].

Fidantemiz et al. [13] used lysimeters under a controlled environment condition to determine the effect of different groundwater table levels $(30,50,70$, and $90 \mathrm{~cm})$ on soybean growth. The highest grain yield and WUE results were obtained from $90 \mathrm{~cm}$ water table depth with $17.2 \mathrm{~g} / \mathrm{lys}$ and $0.31 \mathrm{~g} / \mathrm{lys} . / \mathrm{c}$, respectively. In terms of WUE, grain yield and root distribution, both 70 and $90 \mathrm{~cm}$ water table depths were optimum for soybean yield in the experiments conducted without surface irrigation.

In this current study, canola plants are grown in the lysimeters. Canola can be grown with inadequate irrigation and weather conditions and, therefore, is highly adapted to cold weather conditions with insufficient water availability. High temperatures may cause abiotic stress on canola plant and influences its growth. Canola's sensitivity to high temperatures is higher in the flowering period than the podding period. During the blooming season of the canola plant, heat stress may shorten the flowering period. Two common types of canola, winter (B. rapa) and spring (B. napus) canola, can be grown in North Dakota. Although winter canola can be produced in ND and northwestern Minnesota, ND farmers mainly prefer to plant spring canola since spring canola can survive under the harsh winter condition, and its yield growth is higher than that of winter canola [14-16]. 
The main scope of this study was to determine an optimum shallow groundwater depth to achieve a high yield for canola plants. The lysimeter experiment was conducted to: (1) determine the optimum groundwater depth for canola growth and yield parameters for water table depths of 30,60, and $90 \mathrm{~cm}$ without irrigation, (2) to quantify the amount of water consumption for water table depths of 30,60, and $90 \mathrm{~cm}$ during canola growth, and (3) to determine the canola plant root distribution at water table depths of 30,60, and $90 \mathrm{~cm}$.

\section{Materials and Methods}

\subsection{Lysimeter Design and Preparation}

A greenhouse located in the North Dakota State University campus, Fargo, ND was used for the lysimeter study. Four treatments at $30 \mathrm{~cm}\left(\mathrm{~T}_{30}\right), 60 \mathrm{~cm}\left(\mathrm{~T}_{60}\right)$, and $90 \mathrm{~cm}\left(\mathrm{~T}_{90}\right)$ water table depths with no irrigation application and a control treatment $\left(\mathrm{T}_{\text {control }}\right.$, no water table) with a surface irrigation application were used. These three different water table depths were selected because they represent the elevated water table conditions in the fields where canola is normally grown. Each treatment had eight replications, so a total of 32 lysimeters were used. For the control treatment, $50 \%$ of the total available moisture (TAM) was considered as readily available moisture (RAM) in the soil profile. RAM is defined as the portion of the available water (field capacity minus permanent wilting point) before growth and yield are affected. RAM varies with crop and the evapotranspiration (ET) rates. According to Huffman et al. [17], 50\% of the TAM for canola and a maximal ET rate of $6 \mathrm{~mm} /$ day was recommended. Tap water was used for both the groundwater and irrigation water sources. All the lysimeters in the greenhouse were distributed using a randomized complete block design method with eight replications.

Amber colored class bottles were used as Mariotte bottles to prevent algal growth and connected to the 24 lysimeters used for the water table depth treatments. The volume of the Mariotte bottles were $4 \mathrm{~L}$, and four adjustable shelves were used to adjust the desired water table depth. The variation of the water volume in the Mariotte bottles was measured to determine the water consumption of canola. The Mariotte bottles were connected to the lysimeters from the bottom and continuously fed the lysimeters with a constant flow rate (Figure 1). The water reduction on the Mariotte bottles was monitored, and the difference was considered as the canola water consumption that supplied from the groundwater. Graduated cylinders were used for replenishment in the Mariotte bottles to obtain reliable measured water use.

\subsection{Soil Packing and Sensor Installation}

The loam soil was used to pack all the lysimeters. Bulk soil samples were obtained from an agricultural field in Fergus Falls, MN. The soil texture was classified as a loam soil based on the USDA/FAO texture classification system. The soil was then air-dried and sieved through a $2 \mathrm{~mm}$ screen and packed into the lysimeters. At the beginning of the study, the soil compaction problem in the lysimeters was observed, and $300 \mathrm{~g}$ of sand was added to $1.0 \mathrm{~kg}$ of the soil to deal with this problem. According to the laboratory analysis, the packed soil field capacity, readily available water, permanent wilting point, and bulk density were $0.32 \mathrm{~cm}^{3} / \mathrm{cm}^{3}, 0.27 \mathrm{~cm}^{3} / \mathrm{cm}^{3}, 0.21 \mathrm{~cm}^{3} / \mathrm{cm}^{3}$, and $1.14 \mathrm{Mg} / \mathrm{m}^{3}$, respectively. All these parameters were measured using the combined HYPROP (Data Evaluation Software) and WP4 method [18]. Gravel $(8 \mathrm{~cm})$ was packed at the bottom of the lysimeters, sand $(8 \mathrm{~cm})$ was then packed, and finally the processed loam soil $(100 \mathrm{~cm})$ was used to fill the lysimeters (Figure 1). All lysimeters were packed identically. Each lysimeter's diameter, wall thickness, and height were $152.4 \mathrm{~mm}, 5 \mathrm{~mm}$, and $1260 \mathrm{~mm}$, respectively. The lysimeters were made of Schedule-40 PVC material. The bottoms of the lysimeters were closed with a cap and glued to prevent leaking.

In the control treatment lysimeters $\left(\mathrm{T}_{\text {control }}\right)$, three soil water potential sensors (TEROS-21, METER Group, Inc., Pullman, WA, USA) were used to determine (i) the irrigation timing and (ii) the water needed for irrigation. Water potential sensors were installed at depths of 15,45 , and $75 \mathrm{~cm}$ in 
the lysimeters. For the remaining treatments $\left(T_{30}, T_{60}\right.$, and $\left.T_{90}\right)$, six soil water potential sensors were used and placed at the appropriate depths. One soil water potential sensor was placed at a depth of $15 \mathrm{~cm}$ from the top of the soil surface in the $\mathrm{T}_{30}$ lysimeter. Two soil water potential sensors were placed at depths of 15 and $45 \mathrm{~cm}$ in the $\mathrm{T}_{60}$ lysimeter, and three soil water potential sensors were placed at the depths of 15,45, and $75 \mathrm{~cm}$ in the $\mathrm{T}_{90}$ lysimeter [13]. To ensure hydraulic contact between sensors and moisture in the soil, all the sensors were placed horizontally in the lysimeters. All 9 water potential sensors were plugged into two Em50G (Decagon Inc.) dataloggers, and the data recording time interval was selected as $10 \mathrm{~min}$.

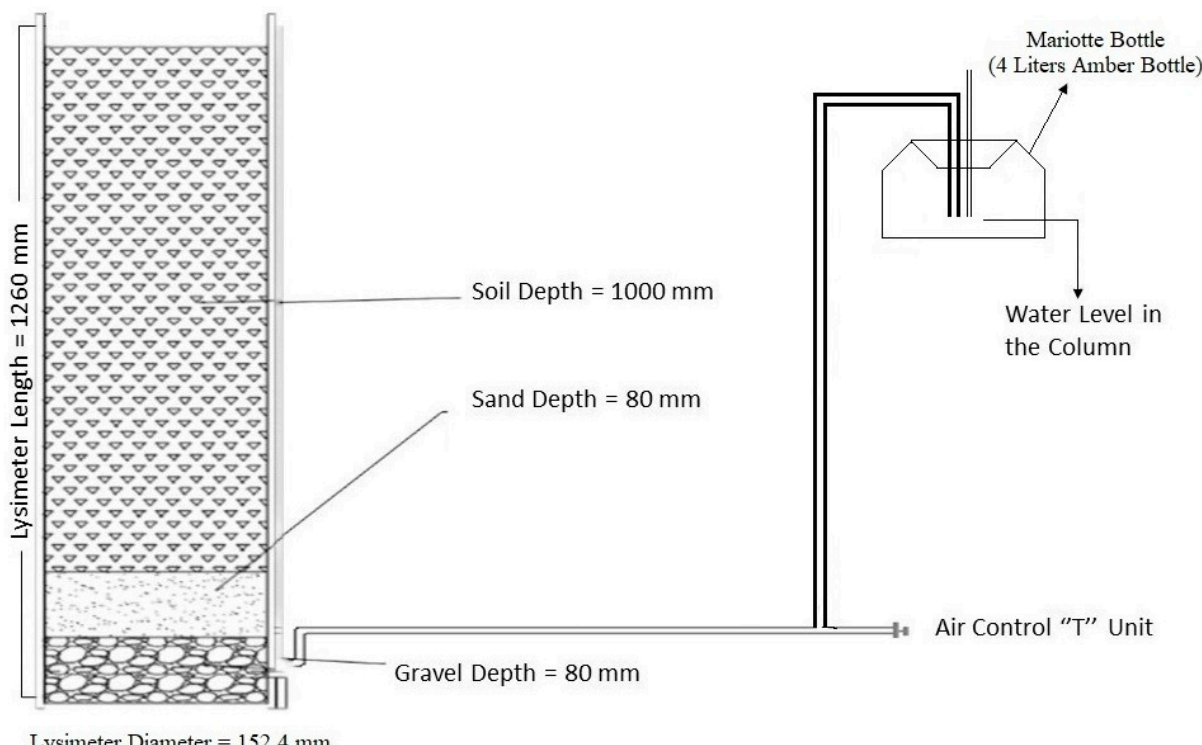

Figure 1. Schematic diagram of a lysimeter and Mariotte bottle system.

Two ETgage model E atmometers (C\&M Meteorological Supply, Colorado Springs, CO, USA) were used to measure reference crop evapotranspiration $\left(\mathrm{ET}_{0}\right)$ in the greenhouse and recorded daily using HOBO Pendant Event Data Loggers (Onset Computer, Bourne, MA, USA) between 4 November 2018 (planting) and 4 February 2019 (harvesting). In addition, air temperature, barometric pressure, relative humidity, and vapor pressure were measured using an Atmos 14 sensor (Decagon Devices, Inc., Pullman, WA, USA). The device was connected to an Em50G datalogger to transfer the data to a computer.

\subsection{Planting and Harvesting of Canola}

Canola seeds (NDOLA-01) were planted on 4 November 2018 and harvested from 4 February to 10 February 2019, according to the plant harvest stages (Table 1). Ten seeds were sowed from 1 to $3 \mathrm{~cm}$ soil depths and thinned so that the three healthiest seedlings remained in each lysimeter. All the planted seeds were germinated in eight days. Although iron deficiency was observed at the beginning of the experiment, beneficial nematodes, supplements, and chemicals were not applied during the experiment. Similarly, no fertilizer was used in this study.

Table 1. Canola harvesting dates.

\begin{tabular}{|c|c|c|c|c|c|c|c|c|}
\hline \multirow{2}{*}{ Treatments } & \multicolumn{8}{|c|}{ Replications } \\
\hline & 1 & 2 & 3 & 4 & 5 & 6 & 7 & 8 \\
\hline $\mathrm{T}_{\text {control }}$ & 5 February & 5 February & 6 February & 6 February & 5 February & 5 February & 5 February & 5 February \\
\hline $\mathrm{T}_{60}$ & 7 February & 6 February & 6 February & 7 February & 6 February & 7 February & 7 February & 7 February \\
\hline $\mathrm{T}_{90}$ & 5 February & 4 February & 5 February & 4 February & 5 February & 4 February & 4 February & 4 February \\
\hline
\end{tabular}


To provide identical water curve conditions at the beginning of the experiment, all the lysimeters were filled with water to the soil surface in the lysimeters. Then, the valves at the bottom of the lysimeters were opened, and water in the lysimeters was drained. Approximately $30 \mathrm{~h}$ later, the valves were closed to maintain adequate moisture in the lysimeters for germination and the Mariotte bottles were connected and adjusted for the desired water table level for each lysimeter. For the control experiments, surface irrigation was applied based on the data obtained from the sensors, regardless of the germination stage in the lysimeters. Thus, starting from the first irrigation application, the irrigation timing and the amount of water needed for irrigation were determined by considering only the sensors' outcomes. Therefore, the germination stages in the columns were not monitored. As explained earlier, our goal was to maintain the packed soil field capacity at $0.32 \mathrm{~cm}^{3} / \mathrm{cm}^{3}$ and readily available water content at $0.27 \mathrm{~cm}^{3} / \mathrm{cm}^{3}$.

\subsection{Calculation of Crop Water Use from Groundwater and Irrigation Water}

After plant harvest, four randomly selected lysimeters from each treatment were cut vertically to determine the canola plant root's dry mass. In order to analyze the entire root distribution in each treatment, lysimeters were cut from the top through the bottom using electric saw. During the soil extraction process, three plant root depth intervals $(0-30,30-60$, and $60-90 \mathrm{~cm})$ were selected based on three water table depths. The soil in the lysimeters was washed, and the roots were separated gently from the soil. The roots were air-dried for $24 \mathrm{~h}$ before weighing to determine the root distribution and dry mass at each depth interval. Evapotranspiration in each lysimeter was calculated using Equation (1):

$$
(\Delta \mathrm{S})=(\mathrm{I}+\mathrm{Cr})-(\mathrm{Dp}+\mathrm{ET})
$$

where $\mathrm{Cr}$ is the water inflow due to capillarity, I is the irrigation, $\mathrm{Dp}$ is the deep percolation, ET is the evapotranspiration, and $\Delta S$ is the change in soil water content. Precipitation, runoff, and deep percolation were not applicable in this study since the experiments was performed in a controlled greenhouse. Irrigation was only applied to the control experiments. After evaluation of the controlled environment's conditions, the soil water balance equation was used to determine ET for each treatment (Equation (2)):

$$
\mathrm{ET}=\mathrm{Cr}+\mathrm{S}_{1}-\mathrm{S}_{2}
$$

where $S_{1}$ is the initial soil water storage (soil moisture) and $S_{2}$ is the final soil water storage in the lysimeters. Water reduction in the Mariotte bottles was measured every 15 days to determine the capillary water inflow in the lysimeters. The amount of water used by the canola was calculated using the soil water balance equation (Equation (1)) [19].

To determine the initial moisture conditions of the lysimeters at the beginning of the experiment, soil water potential sensors were used. After cutting the sixteen lysimeters, soil water content was measured, and the final moisture conditions of the sixteen lysimeters were determined. The soil water release curve was used to consider $50 \%$ of the total available moisture as the RAM in the soil profile of control treatment. The irrigation water depths for the lysimeters were calculated by using Equation (3) [20]:

$$
\mathrm{d}=\sum_{\mathrm{i}=1}^{\mathrm{n}} \frac{\mathrm{F}_{\mathrm{ci}}-\mathrm{M}_{\mathrm{bi}}}{100} \times \mathrm{A}_{\mathrm{si}} \times \mathrm{D}_{\mathrm{i}}
$$

where $\mathrm{d}$ is the equivalent depth of water in $\mathrm{cm}, \mathrm{F}_{\mathrm{ci}}$ is the field capacity of the soil layer in percent by weight, $\mathrm{M}_{\mathrm{bi}}$ is the current water content of the soil layer in percent by weight, $\mathrm{A}_{\mathrm{si}}$ is the apparent specific gravity (bulk density), $D_{i}$ is the depth of each soil layer, and $\mathrm{n}$ is the total number of soil layers.

To determine the soil water retention curve, the water in each lysimeter was drained out through a valve at the bottom of the lysimeter until $50 \%$ readily available soil moisture content was obtained in the lysimeter. For the control treatment, supplemental water was applied at the surface of the lysimeters to maintain the soil field capacity at $0.32 \mathrm{~cm}^{3} / \mathrm{cm}^{3}$. 
WUE was calculated for both grain yield (harvested seed weight) and total biomass (harvested total dry matter). Since sixteen lysimeters were cut, the grain yield and total biomass values of sixteen lysimeters were used for grain yield and biomass WUE calculations. The same statistical difference in the grain yield and total biomass WUE results of thirty-two lysimeters was extrapolated by using the data of sixteen lysimeters in response to different WTDs.

\subsection{Statistical Analysis}

A randomized complete block design method was used in this study. The effect of different groundwater levels on canola growth and yield parameters (crop water use, plant height, seed weight, pod weight, total biomass, root-shoot ratio, and root distribution) were analyzed by using a one-way analysis of variance (ANOVA) with a $P \leq 0.05$ level of significance. The Statistical Package for the Social Sciences version 25 (SPSS) and Duncan homogeneous test comparisons with the $P=0.05$ probability level were used to conduct mean separation tests, when appropriate.

\section{Results and Discussions}

\subsection{Evapotranspiration and Climate Conditions in the Greenhouse}

To determine the relationship between evapotranspiration and temperature in the greenhouse and interpret the temperature and $\mathrm{ET}_{0}$ changes during the different canola growing stages (germination, growing, and harvesting), daily average $\mathrm{ET}_{0}$ rates and temperature data were collected between 4 November 2018 (planting) and 4 February 2019 (first harvesting). According to the result obtained from ETgages, the lowest and highest temperature in the greenhouse were determined as $15.5^{\circ} \mathrm{C}$ and $29.5^{\circ} \mathrm{C}$, respectively (Figure 2). The lowest temperatures were observed during the first 10 days after planting because of extreme cold ambient temperatures. The temperatures in the greenhouse were $25 \pm 5^{\circ} \mathrm{C}$ from 14 November 2018 to 4 February 2019.

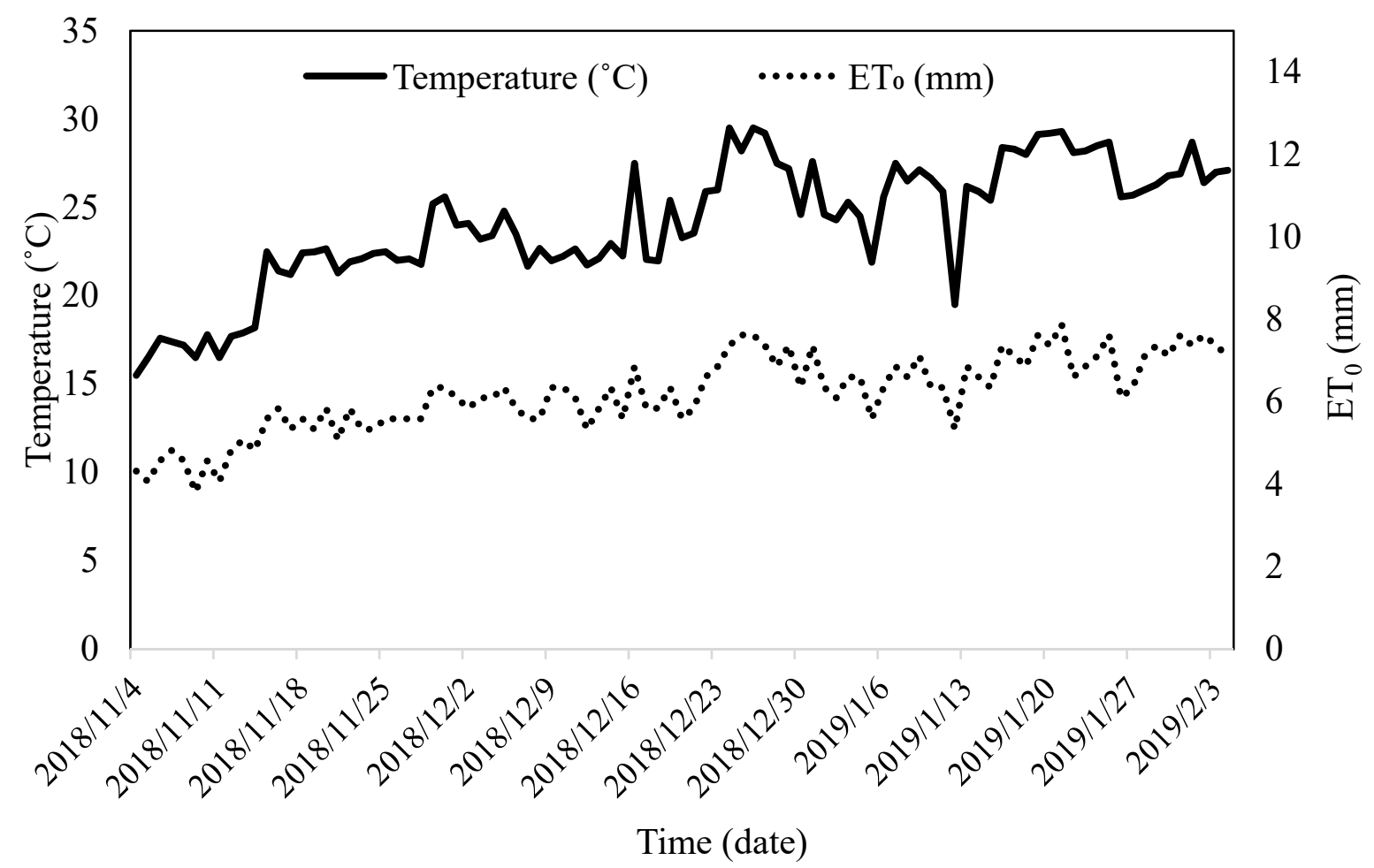

Figure 2. Measured daily air temperature $\left({ }^{\circ} \mathrm{C}\right)$ and $\mathrm{ET}_{0}$ values in the greenhouse. $\left(\mathrm{ET}_{0}\right.$ is reference crop evapotranspiration). 
The lowest daily $\mathrm{ET}_{0}$ was measured as $3.80 \mathrm{~mm}$ during the germination stage of canola (Figure 2). After 10 days of planting (when the canola was germinating and emerging), $\mathrm{ET}_{0}$ rates fluctuated, with the highest $\mathrm{ET}_{0}$ measured at $7.80 \mathrm{~mm}$. Cumulative $\mathrm{ET}_{0}$ was calculated as $577 \mathrm{~mm}$ during the entire experimental period (92 days). Fluctuations in air temperature influenced evapotranspiration. When the greenhouse temperature dropped from time to time, $\mathrm{ET}_{0}$ also decreased accordingly.

\subsection{Canola Irrigation Water Use}

In the control treatment, the water content was kept between the field capacity $\left(0.32 \mathrm{~cm}^{3} / \mathrm{cm}^{3}\right)$ and the RAM $\left(0.27 \mathrm{~cm}^{3} / \mathrm{cm}^{3}\right)$ in order to prevent water stress and the application of an excessive amount of irrigation water. Three different plant root depths were considered for water requirement calculations. The canola root depth was projected $30 \mathrm{~cm}$ between 4 November and 4 December 2018 for the calculation of crop water requirements. Between 4 December 2018 and 4 January 2019, the control plants were irrigated up to a $60 \mathrm{~cm}$ root depth. After 4 January 2019, the crop water requirement was calculated for a $90 \mathrm{~cm}$ root depth. The volumetric water content for the specified root depths of the control plants was always maintained between field capacity and RAM with supplemental watering (Figure 3).
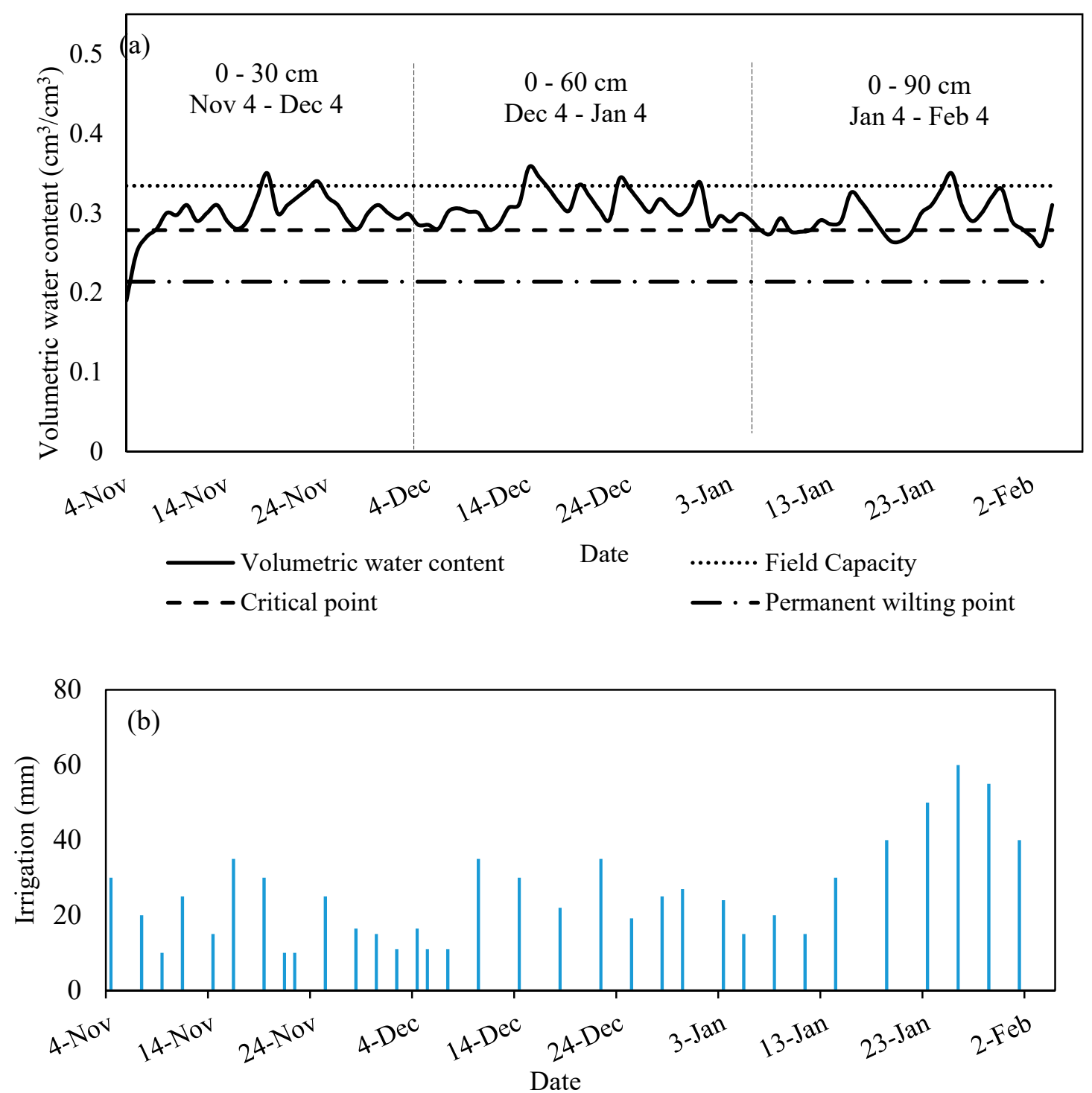

Figure 3. (a) Soil moisture content measurements for the control treatment at the desired depth of soil profile and (b) irrigation water applied to the lysimeters. 
Control lysimeters received $752 \mathrm{~mm}$ of cumulative irrigation water. The calculated cumulative canola plant water use varied from 733 to $749 \mathrm{~mm}$, with an average $\mathrm{ET}_{\mathrm{c}}$ of $740 \mathrm{~mm}$ for the control treatments (Table 2).

Table 2. Total canola water-use for the control treatments.

\begin{tabular}{cccccc}
\hline $\begin{array}{c}\text { Lysimeter } \\
\text { Number }\end{array}$ & Initial Condition & $\begin{array}{c}\text { Cumulative } \\
\text { Irrigation Water }\end{array}$ & Final Condition & $\begin{array}{c}\text { Cumulative } \\
\text { ET }_{\mathbf{c}}\end{array}$ & $\begin{array}{c}\text { Mean } \\
\text { ET }_{\mathbf{c}}\end{array}$ \\
\hline$\#$ & $\mathrm{~mm}$ & $\mathrm{~mm}$ & $\mathrm{~mm}$ & $\mathrm{~mm}$ & $\mathrm{~mm}$ \\
\hline $\mathrm{R}_{3}-\mathrm{T}_{\text {control }}$ & 162 & 752 & 181 & 733 & \\
$\mathrm{R}_{4}-\mathrm{T}_{\text {control }}$ & 162 & 752 & 174 & 740 & 740 \\
$\mathrm{R}_{6}-\mathrm{T}_{\text {control }}$ & 162 & 752 & 165 & 749 & \\
$\mathrm{R}_{7}-\mathrm{T}_{\text {control }}$ & 162 & 752 & 176 & 738 & \\
\hline
\end{tabular}

\subsection{Canola Groundwater Use}

The total canola plant water use and the groundwater contribution for the 12 lysimeters (3 lysimeters from each treatment) are presented in Table 3. Data collected from the water potential sensors were used to calculate soil water content. Initial soil water content was $350 \mathrm{~mm}$ in all the lysimeters. Similar to the control treatments, the canola evapotranspiration values in the water table treatments were measured. Each root depth had different $\mathrm{ET}_{\mathrm{c}}$ values because evapotranspiration was influenced by WTD (Table 3). According to the $\mathrm{ET}_{\mathrm{c}}$ value comparisons from different WTDs, the $30 \mathrm{~cm}$ soil profile had the highest $\mathrm{ET}_{\mathrm{c}}, 717 \mathrm{~mm}$. A significant difference in $\mathrm{ET}_{\mathrm{c}}$ was observed between the 30 and $90 \mathrm{~cm}$ soil profiles. These results showed an inverse relationship between WTD and evapotranspiration. Additionally, the same inverse relationship was obtained between WTD and groundwater contribution. When the water table depth increased from 30 to $90 \mathrm{~cm}$, the amount of water use from the groundwater also increased.

Table 3. Total canola water use from the groundwater for different depths.

\begin{tabular}{cccccccc}
\hline $\begin{array}{c}\text { Lysimeter } \\
\text { Number }\end{array}$ & Depth & $\begin{array}{c}\text { Initial } \\
\text { Condition }\end{array}$ & $\begin{array}{c}\text { Water Use } \\
\text { from GW }\end{array}$ & $\begin{array}{c}\text { Final } \\
\text { Condition }\end{array}$ & $\mathbf{E T}_{\mathbf{c}}$ & Mean ET $_{\mathbf{c}}$ & ${\text { Mean } \mathbf{E T}_{\mathbf{c}}}^{*}$ \\
\hline $\mathrm{cm}$ & $\mathrm{mm}$ & $\mathrm{mm}$ & $\mathrm{mm}$ & $\mathrm{mm}$ & $\mathrm{mm}$ & $\%_{\text {control }}$ \\
\hline $\mathrm{R}_{3}$ & 30 & 350 & 632 & 241 & 741 & & \\
$\mathrm{R}_{4}$ & 30 & 350 & 615 & 268 & 697 & 717 & 97 \\
$\mathrm{R}_{6}$ & 30 & 350 & 643 & 245 & 748 & & \\
$\mathrm{R}_{7}$ & 30 & 350 & 607 & 275 & 682 & & \\
\hline $\mathrm{R}_{3}$ & 60 & 350 & 485 & 279 & 556 & & \\
$\mathrm{R}_{4}$ & 60 & 350 & 426 & 289 & 487 & 527 & \\
$\mathrm{R}_{6}$ & 60 & 350 & 433 & 271 & 512 & & \\
$\mathrm{R}_{7}$ & 60 & 350 & 454 & 251 & 553 & & \\
\hline $\mathrm{R}_{3}$ & 90 & 350 & 402 & 235 & 517 & & \\
$\mathrm{R}_{4}$ & 90 & 350 & 355 & 225 & 480 & 501 & \\
$\mathrm{R}_{6}$ & 90 & 350 & 379 & 214 & 515 & & \\
$\mathrm{R}_{7}$ & 90 & 350 & 341 & 198 & 493 & & \\
\hline \multicolumn{7}{c}{ Note: $\mathrm{R}$ denotes replication. The initial condition is assumed to be identical for all lysimeters. }
\end{tabular}

\subsection{Growth and Yield Parameters}

Plants in the $\mathrm{T}_{90}$ treatments were taller than the plants in the $\mathrm{T}_{\text {control }}, \mathrm{T}_{30}$, and $\mathrm{T}_{60}$ treatments, with a mean plant height of $134.6 \mathrm{~cm}$ for plants in the $T_{90}$ treatment, while the shortest plants $(113.3 \mathrm{~cm})$ were in the $\mathrm{T}_{30}$ treatment. An inverse relationship was observed between the mean plant height and WTD, which was similar to the relationship between the WTD and the groundwater contribution. 
When the water level was increased from 90 to $60 \mathrm{~cm}$ (measured from the soil surface) in the lysimeters, the canola plant height decreased from 134.6 to $113.3 \mathrm{~cm}$.

Treatment differences were significant for total biomass, pod weight, and seed weight per plant (Table 4). The highest mean total biomass, pod weight, and seed weight were 22.1, 12.6, and $6.3 \mathrm{gr}$, respectively, for the $T_{90}$ treatment. The lowest mean total biomass, pod weight, and seed weight results were 15.1, 9.5, and $4.8 \mathrm{gr}$, respectively, for the $\mathrm{T}_{30}$ treatment. These results indicate that the shallower water table depth decreased canola harvesting. Overall, the statistical results suggest a negative correlation between the canola plant growth and the yield parameters and WTD. A similar correlation between the WTD and crop harvesting results was reported by Mejia et al. [8]. According to the 2 year lysimeter experiment results, corn and soybean grain yield weights increased when the WTD decreased from $50 \mathrm{~cm}$ to $75 \mathrm{~cm}$ [8].

Plants in the control treatment consumed the most water (Tables 2 and 3), while plants in the $T_{90}$ treatment had the highest yield values compared to other treatmnets (Table 4). As explained earlier, plants in $\mathrm{T}_{\text {control }}$ used the optimum amount of irrigation water, $740 \mathrm{~mm}$, while plants in $\mathrm{T}_{90}$ consumed $501 \mathrm{~mm}$ of water from the groundwater. However, better growth and yield results were obtained from plants in the $\mathrm{T}_{90}$ treatment.

Table 4. Statistical analysis of the canola growth and yield parameters.

\begin{tabular}{ccccc}
\hline Treatment \# & $\begin{array}{c}\text { Plant Height } \\
\text { cm/plant }\end{array}$ & $\begin{array}{c}\text { Total Biomass } \\
\text { g/plant }\end{array}$ & $\begin{array}{c}\text { Pod Weight } \\
\text { g/plant }\end{array}$ & $\begin{array}{c}\text { Seed Weight } \\
\text { g/plant }\end{array}$ \\
\hline $\mathrm{T}_{\text {control }}$ & $118.0^{\mathrm{a}}$ & $19.4^{\mathrm{c}}$ & $11.7^{\mathrm{c}}$ & $5.8^{\mathrm{c}}$ \\
$\mathrm{T}_{30}$ & $113.2^{\mathrm{a}}$ & $15.1^{\mathrm{a}}$ & $9.5^{\mathrm{a}}$ & $4.7^{\mathrm{a}}$ \\
$\mathrm{T}_{60}$ & $113.8^{\mathrm{a}}$ & $17.8^{\mathrm{b}}$ & $10.8^{\mathrm{b}}$ & $5.3^{\mathrm{b}}$ \\
$\mathrm{T}_{90}$ & $134.6^{\mathrm{b}}$ & $22.0^{\mathrm{d}}$ & $12.5^{\mathrm{d}}$ & $6.3^{\mathrm{d}}$ \\
\hline
\end{tabular}

Note: Lowercase letters; ${ }^{\mathrm{a}},{ }^{\mathrm{b}}, \mathrm{c}$, and ${ }^{\mathrm{d}}$ show statistical significance at $p=0.05$. The values followed by the same letter in each column are not significantly different.

\subsection{Water Use Efficiency (WUE)}

The relationship between WUE for canola total biomass and grain yield was significant. The correlation of both WUE values was also determined (Figure 4). The effects of different WTD levels on both the grain yield and total biomass WUEs were also significant. The highest grain yield and biomass WUE values for $T_{90}$ were 0.0126 and $0.0449 \mathrm{~g} \mathrm{lys}^{-1} \mathrm{~mm}^{-1}$, respectively. The lowest WUE values for both parameters occurred with the $\mathrm{T}_{30}$ treatment (Table 5).

After cutting the 16 lysimeters as mentioned earlier, each soil profile was divided into three different layers: 0-30, 30-60, and 60-90 cm (measured from the top) to determine the percentage of the root mass distribution in terms of WTD (Table 6). Overall, the highest root-mass ratio was found with plants in $\mathrm{T}_{\text {control }}$ at the $0-30 \mathrm{~cm}$ soil layer (4.52 $\mathrm{g}$ and $54.6 \%$ ). There was an inverse relationship between soil depth and root mass distribution for $\mathrm{T}_{\text {control }}$ plants. When WTD changed from 90 to $30 \mathrm{~cm}$, the root weight increased from 0.73 to $4.52 \mathrm{~g}$. Since $\mathrm{T}_{\text {control }}$ did not have WTD, a lower amount of roots was found in deeper soil layers. Significant differences were observed in $0-30 \mathrm{~cm}$ between $\mathrm{T}_{90}$ and other treatments, and a greater root mass was observed at $60-90 \mathrm{~cm}$ in treatment $\mathrm{T}_{90}$. The highest average root weight was $7.97 \mathrm{~g}$ in the third layer for plants in the $\mathrm{T}_{90}$ treatment (Table 6). Similar to the inverse relationship between the soil depth and root mass for $\mathrm{T}_{\text {control, }}$, an inverse correlation was observed between WTD and the root mass for $\mathrm{T}_{90}$. 


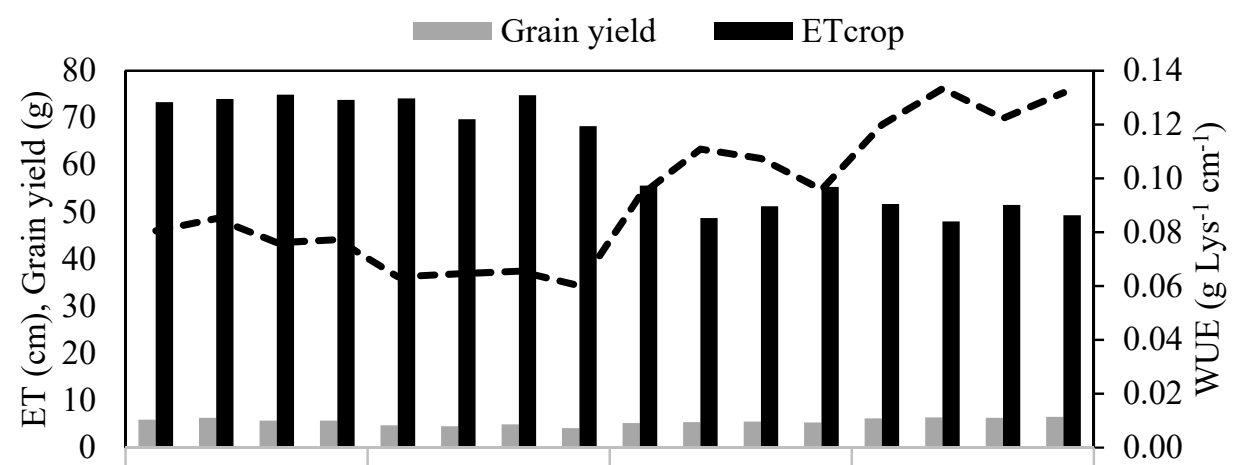

\begin{tabular}{llll|llll|llll|llll}
$\mathrm{R}_{3}$ & $\mathrm{R}_{4}$ & $\mathrm{R}_{6}$ & $\mathrm{R}_{7}$ & $\mathrm{R}_{3}$ & $\mathrm{R}_{4}$ & $\mathrm{R}_{6}$ & $\mathrm{R}_{7}$ & $\mathrm{R}_{3}$ & $\mathrm{R}_{4}$ & $\mathrm{R}_{6}$ & $\mathrm{R}_{7}$ & $\mathrm{R}_{3}$ & $\mathrm{R}_{4}$ & $\mathrm{R}_{6}$ & $\mathrm{R}_{7}$
\end{tabular} \begin{tabular}{l|l|l|r}
$\mathrm{T}_{\text {control }}$ & $\mathrm{T}_{30}$ & $\mathrm{~T}_{60}$ & $\mathrm{~T}_{90}$
\end{tabular} Treatments \& Replications

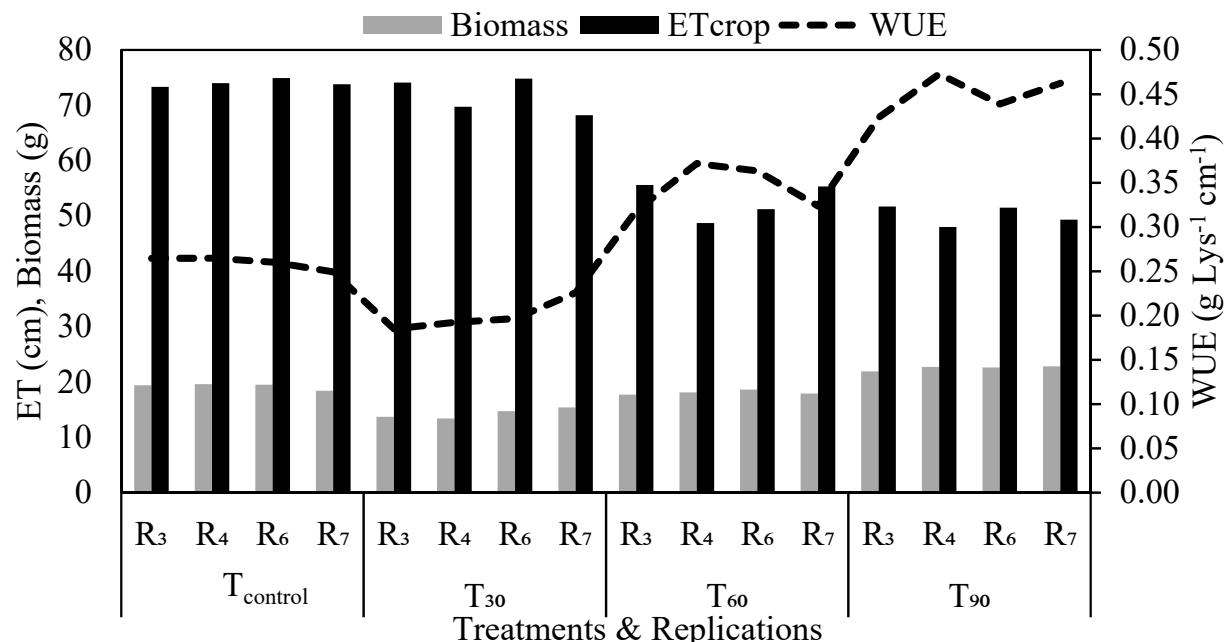

Figure 4. Canola water use efficiency with treatments: (a) grain yield water use efficiency (WUE) and (b) total biomass WUE.

Table 5. Statistical analysis results of the canola's mean grain yield, total biomass, water use, and water use efficiency.

\begin{tabular}{cccccc}
\hline Treatment & $\begin{array}{c}\text { Mean Grain } \\
\text { Yield (g/lys) }\end{array}$ & $\begin{array}{c}\text { Mean Total } \\
\text { Biomass (g/lys) }\end{array}$ & $\begin{array}{c}\text { Mean Crop } \\
\text { Water Use (mm) }\end{array}$ & $\begin{array}{c}\text { Mean Grain Yield } \\
\text { WUE (g/lys·mm) }\end{array}$ & $\begin{array}{c}\text { Mean Total Biomass } \\
\text { WUE (g/lys·mm) }\end{array}$ \\
\hline $\mathrm{T}_{\text {control }}$ & $5.9^{\mathrm{c}}$ & $19.2^{\mathrm{c}}$ & $740.0^{\mathrm{b}}$ & $0.0079^{\mathrm{b}}$ & $0.0259^{\mathrm{b}}$ \\
$\mathrm{T}_{30}$ & $4.5^{\mathrm{a}}$ & $14.3^{\mathrm{a}}$ & $717.0^{\mathrm{b}}$ & $0.0063^{\mathrm{a}}$ & $0.0199^{\mathrm{a}}$ \\
$\mathrm{T}_{60}$ & $5.3^{\mathrm{b}}$ & $18.0^{\mathrm{b}}$ & $527.0^{\mathrm{a}}$ & $0.0101^{\mathrm{c}}$ & $0.0344^{\mathrm{c}}$ \\
$\mathrm{T}_{90}$ & $6.3^{\mathrm{d}}$ & $22.5^{\mathrm{d}}$ & $501.2^{\mathrm{a}}$ & $0.0126^{\mathrm{d}}$ & $0.0449^{\mathrm{d}}$ \\
\hline
\end{tabular}

Note: Lowercase letters; ${ }^{\mathrm{a}},{ }^{\mathrm{b}},{ }^{\mathrm{c}}$, and $^{\mathrm{d}}$ show statistical significance at $p=0.05$. The values followed by the same letter in each column are not significantly different.

Table 6. Average root mass and proportions of roots.

\begin{tabular}{ccccccccccc}
\hline \multirow{2}{*}{ Layers } & \multirow{2}{*}{ Depth } & \multicolumn{8}{c}{ Average Root Mass and Percentage } \\
\cline { 2 - 10 } & & \multicolumn{2}{c}{$\mathbf{T}_{\text {control }}$} & \multicolumn{2}{c}{$\mathbf{T}_{\mathbf{3 0}}$} & \multicolumn{2}{c}{$\mathbf{T}_{\mathbf{6 0}}$} & \multicolumn{2}{c}{$\mathbf{T}_{\mathbf{9 0}}$} \\
\hline & $\mathrm{cm}$ & $\mathrm{g}$ & $\%$ & $\mathrm{~g}$ & $\%$ & $\mathrm{~g}$ & $\%$ & $\mathrm{~g}$ & $\%$ \\
\hline 1th & $0-30$ & $4.52^{\mathrm{b}}$ & 54.6 & $4.4^{\mathrm{b}}$ & 47.8 & $4.60^{\mathrm{b}}$ & 42.9 & $3.13^{\mathrm{a}}$ & 19.1 \\
2nd & $30-60$ & $3.02^{\mathrm{a}}$ & 36.7 & $2.95^{\mathrm{a}}$ & 31.9 & $4.02^{\mathrm{b}}$ & 37.6 & $5.22^{\mathrm{c}}$ & 32.1 \\
3rd & $60-90$ & $0.73^{\mathrm{a}}$ & 8.7 & $1.87^{\mathrm{b}}$ & 20.3 & $2.08^{\mathrm{b}}$ & 19.5 & $7.97^{\mathrm{c}}$ & 48.8 \\
\hline \multicolumn{2}{c}{ Total } & $8.27^{\mathrm{a}}$ & 100 & $9.22^{\mathrm{a}}$ & 100 & $10.7^{\mathrm{b}}$ & 100 & $16.32^{\mathrm{c}}$ & 100
\end{tabular}

Note: Lowercase letters; ${ }^{\mathrm{a}}{ }^{\mathrm{b}}, \mathrm{c}$, and $^{\mathrm{d}}$ show statistical significance at $p=0.05$. The values followed by the same letter in each column are not significantly different. 


\subsection{Root Mass Distribution}

There is no significant total root mass difference between plants in the $\mathrm{T}_{30}$ and $\mathrm{T}_{\text {control }}$ treatments. However, plants in the $\mathrm{T}_{30}$ and $\mathrm{T}_{\text {control }}$ treatments had lower mean total root weights compared to plants in the $\mathrm{T}_{60}$ and $\mathrm{T}_{90}$ treatments. The mean total root mass for plants in the $\mathrm{T}_{90}$ treatment was always two-fold that for $\mathrm{T}_{\text {control }}$. A relatively lower dry root mass was measured at the second and third layers of $\mathrm{T}_{\text {control}}, \mathrm{T}_{30}$, and $\mathrm{T}_{60}$ but a higher dry root mass was found at the second and third layers of $\mathrm{T}_{90}$. Similar to the results of the grain yield, the plant height, total biomass, pod weight, and WUE, the best root mass results were obtained from $\mathrm{T}_{90}$. Fidantemiz et al. [13] found similar results for the T90 treatment. Their results also showed the inverse relationship between the WTD and root mass distribution.

\section{Conclusions}

In this study, the canola plant height, water use from different groundwater levels, total biomass WUE, grain yield WUE, root mass, root-shoot ratio, and harvesting results (total biomass, pod and seed weight) were determined and compared with three different water table depths in a greenhouse. In addition, the effects of the optimum amount of irrigation water and different WTDs on canola were exanimated. Results suggest that the canola plant was affected by different water table levels since inverse linear relationships were found with the different WTDs.

The highest measured pod weight, total biomass, and seed weight were found for plants with the $\mathrm{T}_{90}$ treatment, although plants from this treatment consumed the lowest amount of water from the groundwater. Plants with the greatest harvest results and the lowest amount of water utilization also had the greatest total biomass and grain yield WUEs. On the other hand, plants with the lowest harvest results and the highest crop water use occurred when plants were at the $30 \mathrm{~cm}$ water table depth. As a result, a high WTD level $(30 \mathrm{~cm})$ negatively impacted the canola growth.

Significant statistical differences were found between the root distribution and soil layers. In addition, stronger and heavier roots were found near the water table level. In contrast, the total root weight was affected by WTD, and significant statistical differences were observed among the treatments. The total root weight of the $90 \mathrm{~cm}$ lysimeter was significantly higher than that of the other treatments. It was projected that canola in a drier lysimeter developed its root structure very well, since canola plants have a tendency to reach the water. Overall, the results from this study can be used to guide water management through drainage water management, in order to achieve the best yield potential.

Author Contributions: Conceptualization, H.S., X.C. and X.J.; methodology, H.S., X.J. and H.A.; investigation, H.S.; resources, H.H.-V., H.A.; writing-original draft preparation, H.K.; writing-review and editing, H.H.-V., X.J., X.C., H.S.; supervision, H.S.; funding acquisition, H.S.

Funding: This research was funded by USDA-NIFA North Central Region Canola Research (grant number FAR0029510), North Dakota Water Resources Research Institute (Grant number FAR0025807), and North Dakota Agricultural Extension Station. Additionally, the Turkish Government Ministry of Education (YLSY program) and General Directorate of State Hydraulic Works (DSI) provided stipend and tuition funding for the M.S. student, Hakan Kadioglu.

Acknowledgments: We thank our colleagues Hans Kendal and Mukhlesur Rahman from Plant Science Department and Aaron L.M. Daigh from Soil Science Department at North Dakota State University for their valuable suggestions throughout the study. We are also immensely grateful to Izzet Kadioglu from Plant Protection Department at Gaziosmanpasa University, Tokat, Turkey for his support and encouragement during our experiments. Any opinions, findings, conclusions, or recommendations expressed in this material are those of the author(s) and do not necessarily reflect the views of the funding institutions.

Conflicts of Interest: The authors declare no conflict of interest.

\section{References}

1. Hamdy, A.; Ragab, R.; Scarascia-Mugnozza, E. Coping with water scarcity: Water saving and increasing water productivity. Irrig. Drain. 2003, 52, 3-20. [CrossRef] 
2. Condon, A.G.; Richards, R.; Rebetzke, G.; Farquhar, G. Breeding for high water-use efficiency. J. Exp. Bot. 2004, 55, 2447-2460. [CrossRef] [PubMed]

3. Ripoll, J.; Urban, L.; Staudt, M.; Lopez-Lauri, F.; Bidel, L.P.; Bertin, N. Water shortage and quality of fleshy fruits-Making the most of the unavoidable. J. Exp. Bot. 2014, 65, 4097-4117. [CrossRef] [PubMed]

4. Sinclair, T.R.; Tanner, C.; Bennett, J. Water-use efficiency in crop production. Bioscience 1984, 34, 36-40. [CrossRef]

5. Howell, T.A. Enhancing water use efficiency in irrigated agriculture. Agron. J. 2001, 93, 281-289. [CrossRef]

6. Yang, J.; Wan, S.; Deng, W.; Zhang, G. Water fluxes at a fluctuating water table and groundwater contributions to wheat water use in the lower Yellow River flood plain, China. Hydrol. Process. Int. J. 2007, 21, 717-724. [CrossRef]

7. Ghamarnia, H.; Golamian, M.; Sepehri, S.; Arji, I.; Rezvani, V. Groundwater contribution by safflower (Carthamus tinctorius L.) under high salinity, different water table levels, with and without irrigation. J. Irrig. Drain. Eng. 2011, 138, 156-165. [CrossRef]

8. Mejia, M.; Madramootoo, C.; Broughton, R. Influence of water table management on corn and soybean yields. Agric. Water Manag. 2000, 46, 73-89. [CrossRef]

9. Huo, Z.; Feng, S.; Huang, G.; Zheng, Y.; Wang, Y.; Guo, P. Effect of groundwater level depth and irrigation amount on water fluxes at the groundwater table and water use of wheat. Irrig. Drain. 2012, 61, 348-356. [CrossRef]

10. Luo, Y.; Sophocleous, M. Seasonal groundwater contribution to crop-water use assessed with lysimeter observations and model simulations. J. Hydrol. 2010, 389, 325-335. [CrossRef]

11. Kruse, E.; Champion, D.; Cuevas, D.; Yoder, R.; Young, D. Crop water use from shallow, saline water tables. Trans. ASAE 1993, 36, 697-707. [CrossRef]

12. Talebnejad, R.; Sepaskhah, A. Effect of different saline groundwater depths and irrigation water salinities on yield and water use of quinoa in lysimeter. Agric. Water Manag. 2015, 148, 177-188. [CrossRef]

13. Fidantemiz, Y.F.; Jia, X.; Daigh, A.L.; Hatterman-Valenti, H.; Steele, D.D.; Niaghi, A.R.; Simsek, H. Effect of Water Table Depth on Soybean Water Use, Growth, and Yield Parameters. Water 2019, 11, 931. [CrossRef]

14. Johnston, A.M.; Tanaka, D.L.; Miller, P.R.; Brandt, S.A.; Nielsen, D.C.; Lafond, G.P.; Riveland, N.R. Oilseed crops for semiarid cropping systems in the northern Great Plains. Agron. J. 2002, 94, 231-240. [CrossRef]

15. Kandel, H. Soybean Production Field Guide for North Dakota and Northwestern Minnesota; North Dakota State University: Fargo, ND, USA, 2010.

16. Kutcher, H.; Warland, J.; Brandt, S. Temperature and precipitation effects on canola yields in Saskatchewan, Canada. Agric. For. Meteorol. 2010, 150, 161-165. [CrossRef]

17. Huffman, R.L.; Fangmeier, D.D.; Elliot, W.J.; Workman, S.R. Conservation and the Environment. In Soil and Water Conservation Engineering, 7th ed.; Cengage Learning: Boston, MA, USA, 2012; pp. 1-7.

18. Roy, D.; Jia, X.; Steele, D.D.; Lin, D. Development and comparison of soil water release curves for three soils in the red river valley. Soil Sci. Soc. Am. J. 2018, 82, 568-577. [CrossRef]

19. Hillel, D. Environmental Soil Physics: Fundamentals, Applications, and Environmental Considerations; Elsevier: Amsterdam, The Netherlands, 1998.

20. Majumdar, D.K. Irrigation Water Management: Principles and Practice; Prentice-Hall India Pvt. Ltd.: Delhi, India, 2004; p. 500.

(C) 2019 by the authors. Licensee MDPI, Basel, Switzerland. This article is an open access article distributed under the terms and conditions of the Creative Commons Attribution (CC BY) license (http://creativecommons.org/licenses/by/4.0/). 